\title{
Morphometric Parameters of the Human Adult Kidney: An Anatomical Study
}

\author{
Parámetros Morfométricos del Riñon Humano Adulto: Un Estudio Anatómico
}

\begin{abstract}
B.V. Murlimanju*; Buraje Madhuri Kumar*; Naveen Kumar**; K.U. Prashanth*; "Chitra Prakash Rao"; Anitha Guru**; Latha V. Prabhu*\& Chettiar Ganesh Kumar.
\end{abstract}

MURLIMANJU, B. V.; KUMAR, B. M.; KUMAR, N.; PRASHANTH, K. U.; RAO, C. P.; GURU, A.; PRABHU, L. V. \& KUMAR, C. G. Morphometric parameters of the human adult kidney: An anatomical study. Int. J. Morphol., 32(2):656-659, 2014.

SUMMARY: The purpose of this study was to determine the anatomic parameters of the kidney in adults. The Renal lengths, width at superior and inferior poles, thickness at the superior and inferior poles were measured in 151 adult cadaver kidneys. A digital vernier caliper was used for performing the measurements. The data were statistically analyzed. The mean renal length was $8.9 \pm 0.9 \mathrm{~cm}$ on the right side and $9.1 \pm 0.9 \mathrm{~cm}$ on the left side. The mean width of the superior pole of the right kidney was $4.9 \pm 0.6 \mathrm{~cm}$ and the left kidney was $5 \pm 0.7 \mathrm{~cm}$. The width of inferior pole of the right and left kidneys were $4.8 \pm 0.6 \mathrm{~cm}$ and $4.5 \pm 0.7 \mathrm{~cm}$ respectively. The mean thickness of the superior pole of the right kidney was $3 \pm 0.4 \mathrm{~cm}$ and left kidney was $3.2 \pm 0.5 \mathrm{~cm}$. The mean thickness of the inferior pole of the right and left kidneys were $3.1 \pm 0.4 \mathrm{~cm}$ and $3.2 \pm 0.5 \mathrm{~cm}$ respectively. There was no statistical significance with respect to the length of both the kidneys. However there was some data on width and thickness among the right and left side showed the difference which was significant statistically. The present study has provided additional information on the renal morphometry which will be of use to the surgeons and radiologists.

KEY WORDS: Inferior pole; Kidney; Length; Morphometry; Superior pole.

\section{INTRODUCTION}

The deviation of renal parameters from established normal values is an important criterion in diagnosing kidney disease (Kadioglu, 2010; Han \& Babcock, 1985). In the standard textbook of nephrology, the normal length of the kidney was described as $11 \pm 1 \mathrm{~cm}$ on the right side and $11.5 \pm 1 \mathrm{~cm}$ long on the left side (Parisky et al., 1995). The other authors (Andersson et al., 2007; Madsen \& Tisher, 2004) described the parameters like length as 11 and $12 \mathrm{~cm}$ long, 5 and 7 to 7.5 $\mathrm{cm}$ width, 2.5 and $3 \mathrm{~cm}$ thick for the right and left kidneys respectively. Glodny et al. (2009), reported that there is a wide range in kidney sizes. The kidneys of less than $8 \mathrm{~cm}$ long as well as more than $14 \mathrm{~cm}$ could be normal. They proposed that these types of kidneys should not be misunderstood as a sign of cirrhotic kidney or acute renal failure. There are few data available in the literature on renal morphometry which were obtained from the radiological investigations like ultrasound, computed tomogram and nuclear magnetic resonance. But the anatomical studies on renal parameters are scarce and particularly from India are not reported. Since the therapeutic decisions are often based on the results of measurements, accurate and reproducible normal parameters are of importance. Hence the objective of present study was to determine the anatomical renal dimensions in adult kidneys. The purpose was to establish anatomical reference values for renal length, width and thickness.

\section{MATERIAL AND METHOD}

The present study included 151 adult kidneys which were obtained from anatomy laboratory, of which 69 belonged to the right side and 82 were of left side. All the specimens were preserved in $10 \%$ formalin solution. The perinephric fat and renal fascia were removed in all the specimens. The kidneys which had gross pathological changes were excluded from the present study. The length of each kidney was measured from the uppermost edge of the superior pole to the lowest edge of inferior pole. The widths at superior and inferior poles, thickness at superior and inferior poles were also

\footnotetext{
* Department of Anatomy, Manipal University, Centre for Basic Sciences, Kasturba Medical College, Mangalore, India.

** Department of Anatomy, Melaka Manipal Medical College, Manipal University, Manipal, India.
} 
measured. The measurements were performed by using digital vernier caliper by the same two persons. The results were presented as mean \pm SD. Dimensions were analyzed between the right and left sides. The independent ' $t$ ' test was used to compare the means between right and left kidneys. The statistical significance was set at $\mathrm{p}<0.05$. Analysis was performed by using the SPSS version 11.5.

\section{RESULTS}

The mean renal length, superior pole width, thickness and inferior pole width, thickness of the right and left kidneys are shown in Table I. The statistically significant differences were not observed $(\mathrm{p}>0.05)$ between the right and left renal length, width at superior pole and thickness at inferior pole. However the width at inferior pole of right kidney was larger than the left $(\mathrm{p}=0.01)$ and the thickness of superior role was higher on the left side than right side $(\mathrm{p}=0.00)$.

\section{DISCUSSION}

Though there are few clinical studies performed on the morphometry of kidneys in children, same are scarce in adult subjects. Only a few reports have been published on renal measurements in adults (Emamian et al., 1993). It was reported that the changes in kidney length, width and volume could be associated with atherosclerotic kidney disease, arterial hypertension, renal vascular disease and diabetes mellitus or be indicative of these (Glodny et al.). A short kidney length allows chronic renal failure to be easily distinguished from the acute renal failure with normal or enlarged values (Thakur et al., 1997; Emamian et al.). The knowledge about renal dimensions is also useful in managing the patients with vesico ureteric reflux which alters the morphometrical profile of kidney (Dixit et al., 1994). A change in the renal dimensions from one examination to the next might be an indicator of presence or progression of disease. The renal measurements are clinically relevant and are used frequently as the basis for making clinical decisions (Cheong et al., 2007).
In the clinical setup, for everyday situations, measurement of renal length is recommended since the measurement is easy and the obtained values could be compared with values in the reference figures and tables (Emamian et al.). Emamian et al. reported that the median renal lengths were $11.2 \mathrm{~cm}$ on left side and $10.9 \mathrm{~cm}$ on the right side. According to a study by Shin et al. (2009), the mean right and left kidney lengths were $10.7 \pm 0.76$ and $10.9 \pm 0.72$ $\mathrm{cm}$ respectively. The left kidney was significantly $(\mathrm{p}<0.05)$ longer than right kidney. The ultrasonographic measurement of thickness was reported as 43 and $46 \mathrm{mms}$ for the left and right kidneys respectively (Emamian et al.). Kang et al. (2007), measured the renal parameters in renal transplant donors, after nephrectomy, the kidneys were clamped before anastomosis, the length, width, thickness and weight were measured using sterilized vernier calipers and excluding as much perinephric fat as possible.

It was reported that, there will be some error in ultrasound measurements of kidney length and caution should be done when incorporating the ultrasound measurements into surgical decision making (Ferrer et al., 1997). Moorthy \& Venugopal (2011) critically analyzed the advantages and disadvantages of various methods of renal morphometry by reviewing the literature. It was reported that the volume of right kidney was significantly smaller than that of the left and possible explanation given for this was that, since the spleen is smaller than the liver, left kidney has more space for growth. Another explanation given was that, because the left renal artery is shorter and straighter than the right one, increased blood flow in the left artery might result in relatively increased volume (Emamian et al.). As judged from the renal shape index, kidney becomes relatively wider and thicker with age. The possible explanation given for this was relaxation of the abdominal wall with age, so that kidneys are less squeezed in older individuals. This would also explain the broadening which becomes more pronounced for the right kidney, which has been squeezed more because of the liver (Emamian et $a l$.). It was reported that the kidney becomes shorter and thicker with age (Emamian et al.) and that no significant age-related changes occur in the kidney length until the age of sixty, but its size significantly decreases after the seventy years (Lee et al., 1999).

Table I. Showing the comparison of the morphometric data on right and left kidneys $(n=151)$.

\begin{tabular}{lccc}
\hline Values in $\mathrm{cm}$ & Right side $(\mathrm{n}=69)$ & Left side $(\mathrm{n}=82)$ & Statistical significance \\
\hline Kidney length & $8.9 \pm 0.9$ & $9.1 \pm 0.9$ & $\mathrm{p}=0.28$ \\
Width at superior pole & $4.9 \pm 0.6$ & $5 \pm 0.7$ & $\mathrm{p}=0.61$ \\
Thickness at superior pole* & $3 \pm 0.4$ & $3.2 \pm 0.5$ & $\mathrm{p}=0.00$ \\
Width at inferior pole* & $4.8 \pm 0.6$ & $4.5 \pm 0.7$ & $\mathrm{p}=0.01$ \\
Thickness at inferior pole & $3.1 \pm 0.4$ & $3.2 \pm 0.5$ & $\mathrm{p}=0.19$ \\
\hline
\end{tabular}

Values are mean $\pm \mathrm{SD}$, statistical significance (Independent t-test) *p $<0.05$ 
The literature search revealed only one anatomical study (Sampaio \& Mandarim-de-Lacerda, 1989) on the renal morphometry in which the measured parameters included the length, width of superior and inferior poles and the thickness. The average lengths were $10.97 \mathrm{~cm}$ and $11.21 \mathrm{~cm}$ for the right and left kidneys respectively. The other parameters which were measured in that study were, width of the superior pole (right kidney, $6.40 \mathrm{~cm}$ and left kidney, $6.48 \mathrm{~cm}$ ), width of the inferior pole (right kidney was 5.59 $\mathrm{cm}$ and left kidney was $5.39 \mathrm{~cm}$ ) and the thickness of right and left kidneys were $3.21 \mathrm{~cm}$ and $3.37 \mathrm{~cm}$ respectively. Their results (Sampaio \& Mandarim-de-Lacerda) observed that the left kidney presented greater length, greater width and greater thickness than the right kidney.

In the present study, the measured parameters (Table I) were lesser in size compared to the Brazilian study by (Sampaio \& Mandarim-de-Lacerda). These lesser values might be because of racial variations. We believe that, it is not a surprise that the generally built gracile Indian subjects have shorter renal dimensions than the typically more robustly built Brazilian subjects. Most of the studies in the literature observed that the left kidney is longer than the right, but in our study there was no statistical significance among the right and left kidneys with respect to the length. This finding has also been observed in the other studies earlier by few authors (Han \& Babcock, 1985). The present study also observed that the width at the superior pole and thickness at inferior pole were same for both the kidneys.
But the thickness at superior pole was more for the left kidney and the width at inferior pole was more on the right side. These findings though seem to be not significant clinically; they provide a reference among the scientific community in the literature.

The present study has some limitations as sex of subjects was not taken into consideration. This might be a potential limitation of the present study. The effect of sex on renal length has been observed in the literature (Han \& Babcock; Cheong et al.). The interobserver and intraobserver variations were also not evaluated in the present study. Since the kidneys were fixed with formalin, this also has some influence on the results. The present study observed that the clinical data showed higher values compared to anatomical measurement values. In anatomical anthropometry of the kidneys, the coverings of the kidney which include perinephric fat, renal fascia are removed. But the clinical morphometry has included them also into consideration. This factor should be kept in mind and is important in the clinical scenario.

A search of the Indian literature revealed that there is not an established anatomical data for renal dimensions. The results of the present study could be used as a reference for this purpose since establishing an anatomical dimension is necessary for defining the pathological changes in the kidneys. We believe that the present study has determined the anatomical dimensions of kidneys which might be used as a reference by the clinicians.

MURLIMANJU, B. V.; KUMAR, B. M.; KUMAR, N.; PRASHANTH, K. U.; RAO, C. P.; GURU, A.; PRABHU, L. V. \& KUMAR, C. G. Parámetros morfométricos del riñon humano adulto: Un estudio anatómico. Int. J. Morphol., 32(2):656-659, 2014.

RESUMEN: El propósito de este estudio fue determinar los parámetros anatómicos del riñon en los adultos. La longitud renal, ancho de los polos inferior y superior, y grosor de los polos superior e inferior se midieron en riñones de 151 cadáveres adultos. Se utilizó un caliper vernier digital para realizar las mediciones y los datos fueron analizados estadísticamente. La longitud media renal fue $8,9 \pm 0,9$ $\mathrm{cm}$ en el lado derecho y $9,1 \pm 0,9 \mathrm{~cm}$ en el lado izquierda. El ancho promedio del polo superior del riñón derecho fue 4,9 $\pm 0,6 \mathrm{~cm}$ y del riñón izquierdo fue $5 \pm 0,7 \mathrm{~cm}$. El ancho promedio del polo inferior del lado derecho e izquierdo riñones fueron $4,8 \pm 0,6 \mathrm{~cm}$ y $4,5 \pm 0,7 \mathrm{~cm}$, respectivamente. El grosor promedio del polo superior en el riñón del lado derecho fue $3 \pm 0,4 \mathrm{~cm}$ y el izquierdo $3,2 \pm 0,5 \mathrm{~cm}$. El grosor promedio del polo inferior del riñon del lado derecho e izquierdo fueron $3,1 \pm 0,4 \mathrm{~cm}$ y $3,2 \pm 0,5 \mathrm{~cm}$, respectivamente. No hubo diferencia significativa en relación con la longitud de los riñones. Sin embargo hubo algunos datos en ancho y grosor entre el lado derecho e izquierdo que mostraron diferencia significativa. El presente estudio ha proporcionado información adicional sobre la morfometría renal que puede ser de utilidad para los cirujanos y radiólogos.

PALABRAS CLAVE: Polo Inferior; Riñón; Distancia; Morfometría; Polo Superior.

\section{REFERENCES}

Anderson, J. K.; Kabalin, J. N. \& Cadeddu, J. A. Surgical Anatomy of the Retroperitoneum, Adrenals, Kidneys, and Ureters. In: Wein, A. J.; Kavoussi, L. R.; Novick, A. C.; Partin, A. W. \& Peters, C. A. (Eds.). Campbell-Walsh Urology Review Manual. 9th ed. Philadelphia, Saunders Elsevier, 2007. pp.3-37.
Cheong, B.; Muthupillai, R.; Rubin, M. F. \& Flamm, S. D. Normal values for renal length and volume as measured by magnetic resonance imaging. Clin. J. Am. Soc. Nephrol., 2(1):38-45, 2007. 
Dixit, P. K.; Sahai, S. B.; Rath, B.; Garg, A. \& Chowdhury, V. Norms for renal parenchymal volume in Indian children. Indian Pediatr., 31(9):1059-64, 1994.

Emamian, S. A.; Nielsen, M. B.; Pedersen, J. F. \& Ytte, L. Kidney dimensions at sonography: correlation with age, sex, and habitus in 665 adult volunteers. A.J.R. Am. J. Roentgenol., 160(1):83-6, 1993.

Ferrer, F. A.; McKenna, P. H.; Bauer, M. B. \& Miller, S. F. Accuracy of renal ultrasound measurements for predicting actual kidney size. J. Urol., 157(6):2278-81, 1997.

Glodny, B.; Unterholzner, V.; Taferner, B.; Hofmann, K. J.; Rehder, P.; Strasak, A. \& Petersen, J. Normal kidney size and its influencing factors - a 64-slice MDCT study of 1.040 asymptomatic patients. B.M.C. Urol,. 9:19, 2009.

Han, B. K. \& Babcock, D. S. Sonographic measurements and appearance of normal kidneys in children. A.J.R. Am. J. Roentgenol., 145(3):611-6, 1985.

Kadioglu, A. Renal measurements, including length, parenchymal thickness, and medullary pyramid thickness, in healthy children: what are the normative ultrasound values? A.J.R. Am. J. Roentgenol., 194(2):509-15, 2010.

Kang, K. Y.; Lee, Y. J.; Park, S. C.; Yang, C. W.; Kim, Y. S.; Moon, I. S.; Koh, Y. B.; Bang, B. K. \& Choi, B. S. A comparative study of methods of estimating kidney length in kidney transplantation donors. Nephrol. Dial. Transplant., 22(8):23227, 2007.

Lee, B. H.; Ahn, H. J.; Kang, W. H.; Seo, G. H.; Kim, B.; Lee, S. G.; Oh, D. J.; Huh, W.; Kim, Y. G.; Kim, D. J.; Choi, S. H.; Kim, B.; Hwang, S. H. \& Oh, H. Y. Estimation of kidney size by ultrasonography in normal Korean adults. Korean $J$. Nephrol., 18(1):46-51, 1999.

Madsen, K. M. \& Tisher, C. C. Anatomy of the Kidney. In: Brenner, B. M. Brenner \& Rector's the Kidney. $7^{\text {th }}$ ed. Philadelphia, Saunders, 2003. pp.3-72.

Moorthy, H. K. \& Venugopal, P. Measurement of renal dimensions in vivo: A critical appraisal. Indian J. Urol., 27(2):169-75, 2011.

Parisky, Y.; Boswell, W. D.; Raval, J.; Ralls, W. Diagnostic use of ultrasound for kidney and bladder. In: Massry, S.G.; Glassock, R.J. Textbook of Nephrology. $3^{\text {rd }}$ ed. Baltimore, Williams \& Wilkins, 1995.

Sampaio, F. J. \& Mandarim-de-Lacerda, C. A. Morphometry of the kidney. Applied study in urology and imaging. J. Urol. (Paris), 95(2):77-80, 1989.

Shin, H. S.; Chung, B. H.; Lee, S. E.; Kim, W. J.; Ha, H. I. \& Yang, C. W. Measurement of kidney volume with multi-detector computed tomography scanning in young Korean. Yonsei Med. J., 50(2):262-5, 2009.
Thakur, V.; Watkins, T.; McCarthy, K.; Beidl, T.; Underwood, N.; Barnes, K. \& Cook, M. E. Is kidney length a good predictor of kidney volume? Am. J. Med. Sci., 313(2):85-9, 1997.

Correspondence to:

B.V. Murlimanju, M.D.

Assistant Professor

Department of Anatomy

Kasturba Medical College

Manipal University

Mangalore - 575004

INDIA

Email: drmanju_22@rediffmail.com flutemist@gmail.com

Received: 08-08-2012

Accepted: 19-05-2014 